\title{
The Risks of miRNA Therapeutics: In a Drug Target Perspective [Erratum]
}

Zhang S, Cheng Z, Wang Y, Han T. Drug Des Devel Ther. 2021;15:721-733.

The authors have advised that there are errors on page 722 :

Comparison of miRNA Drugs and siRNA Drugs section, first paragraph, "However, 57 siRNA drugs (targeting human proteins/genes) were ongoing or completed clinical trials, including 16 phase I, 16 phase II, eight phase III, 23 terminated/suspended therapeutics (Table 2 and Figure 1A)" should read "However, 65 siRNA drugs are in or have completed clinical trials, including 16 therapeutics in Phase I, 16 in Phase II, 8 in Phase III, 2 approvals, and 23 terminated/suspended (Table 2 and Figure 1A)".
Comparison of miRNA Drugs and siRNA Drugs section, second paragraph, "Beyond our expectation, the targets of the miRNA drug ranged from 30 to 250 in number and almost all miRNA drug* were over 500 and even 1000 , but the si0052NA drug generally targets 1-3 genes (Figure 2B)" should read "Beyond our expectation, the targets of the miRNA drug ranged from 30 to 250 in number and almost all miRNA drug* had over 500 and even 1000 targets, whereas the siRNA drug generally targeted only 1-3 genes (Figure 2B)".

These errors were introduced by the Editorial staff during the publication process.

\section{Publish your work in this journal}

Drug Design, Development and Therapy is an international, peerreviewed open-access journal that spans the spectrum of drug design and development through to clinical applications. Clinical outcomes, patient safety, and programs for the development and effective, safe, and sustained use of medicines are a feature of the journal, which has also been accepted for indexing on PubMed Central. The manuscript management system is completely online and includes a very quick and fair peer-review system, which is all easy to use. Visit http://www. dovepress.com/testimonials.php to read real quotes from published authors. 